\title{
February orchid cover crop improves sustainability of cotton production systems in the Yellow River basin
}

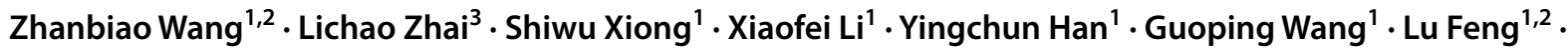 \\ Zhengyi Fan $^{1} \cdot$ Yaping Lei ${ }^{1} \cdot$ Beifang Yang ${ }^{1} \cdot$ Fangfang Xing ${ }^{1} \cdot$ Minghua Xin ${ }^{1} \cdot$ Wenli Du ${ }^{1} \cdot$ Yabing Li $^{1}{ }^{1,2}$
}

Accepted: 22 July 2021 / Published online: 4 October 2021

(c) The Author(s) 2021

\begin{abstract}
Cotton-winter fallow is the major cropping system of cotton in the Yellow River basin of China, which not only leads to a considerable waste of land and natural resources, but also high greenhouse emissions and a loss of reactive nitrogen. Replacing winter bare fallow in cotton production with February orchid as a cover crop is a new cropping system in this area, but its sustainability is still unknown. Therefore, a field experiment was conducted with two cropping systems (cotton-winter fallow and cotton-February orchid) under four nitrogen application rates $\left(0,112.5,168.75\right.$, and $\left.225 \mathrm{~kg} \mathrm{~N} \mathrm{ha}^{-1}\right)$. Field observations were incorporated into a life cycle assessment to estimate the carbon footprint, nitrogen footprint, net ecosystem economic benefits, and economic benefits. The estimated carbon footprint per unit of sown area was 43.6-76.1\% lower in the cottonFebruary orchid system than in the cotton-winter fallow system, mainly because of the increase in soil organic carbon. The cotton-February orchid system significantly increased the nitrogen footprint per unit of sown area by $6.7-11.5 \%$ under different application rates mainly because of the increase in $\mathrm{N}_{2} \mathrm{O}$ emissions. The nitrogen application rate significantly impacted the carbon and nitrogen footprints. After accounting for changes in the nitrogen and carbon footprints, the cotton-February orchid system with $168.75 \mathrm{~kg} \mathrm{~N} \mathrm{ha}^{-1}$, which resulted in the highest net ecosystem economic benefits and economic benefits, resulted in a $25.0 \%$ reduction in nitrogen fertilizer applied and a $9.5 \%$ increase in net ecosystem economic benefits compared with the conventional cotton-winter fallow system and nitrogen fertilizer application rate $\left(225.75 \mathrm{~kg} \mathrm{~N} \mathrm{ha}^{-1}\right)$. Thus, adopting an integrated strategy combining February orchid as a cover crop and a reduced nitrogen fertilizer application contributes to improvements in green and sustainable cotton production systems in the Yellow River basin and other regions with similar ecological conditions.
\end{abstract}

Keywords Carbon footprint $\cdot$ Nitrogen footprint $\cdot$ Environmental damage costs $\cdot$ Net ecosystem economic benefit

Zhanbiao Wang and Lichao Zhai contributed equally to this work.

Zhanbiao Wang

wang_zhanbiao@126.com

Yabing Li

criliyabing1@163.com

1 State Key Laboratory of Cotton Biology, Institute of Cotton Research, Chinese Academy, Agricultural Sciences, Anyang 455000, Henan, China

2 Zhengzhou Research Base, State Key Laboratory of Cotton Biology, School of Agricultural Sciences, Zhengzhou University, Zhengzhou 450001, Henan, China

3 Institute of Cereal and Oil Crops, Hebei Academy of Agricultural and Forestry Science, Key Laboratory of Crop Cultivation Physiology and Green Production of Hebei Province, Shijiazhuang 050035, Hebei Province, China

\section{Introduction}

Environmental degradation from anthropogenic activities has become a major problem worldwide (Warner et al. 2010). In recent decades, anthropogenic greenhouse gas (GHG) emissions have become a global concern because they are the main cause of global climate change (IPCC 2014). Agricultural activities emit 1.4-1.6 $\times 10^{9} \mathrm{t} \mathrm{CO}_{2}$ equivalent $\left(\mathrm{CO}_{2}\right.$ eq $) \mathrm{a}^{-1}$ GHG emissions globally, which is equivalent to $10-12 \%$ of the total anthropogenic GHG emissions (IPCC 2014). Moreover, agriculture leads to significant emissions of reactive nitrogen species to the environment by leaching into groundwater and surface water or emission into the atmosphere, and such species then lead to environmental degradation (e.g., water eutrophication, fog, haze, and stratospheric ozone depletion) (Galloway 
et al. 2008). Thus, it is of utmost importance to quantify and reduce GHG emissions and reactive nitrogen loss from agriculture to mitigate climate change and environmental degradation (Ju et al. 2009).

The carbon footprint (CF) and nitrogen footprint (NF) concepts have been used to quantify and evaluate GHG emissions and nitrogen loss from agroecosystems with the goal of mitigating climate change and environmental degradation (Cai et al. 2018; Xue et al. 2016). The CF is an indicator that expresses the total amount of GHG emissions from a production system and is used to evaluate and mitigate climate change (ISO 2013; Xue et al. 2016). The NF describes the total amount of nitrogen loss due to anthropogenic activities and is used to evaluate and mitigate environmental degradation (e.g., water eutrophication and stratospheric ozone depletion) (Leach et al. 2012; Xue et al. 2016). Other studies have assessed the CF or NF magnitude and composition for crop production to determine management practices that result in a high yield with low environmental consequences to achieve sustainable agricultural development (Cheng et al. 2011; Gan et al. 2012; Xue et al. 2016). Cheng et al. (2011) reported that China's crop production had a high CF with a mean of $119.5 \mathrm{Mt} \mathrm{CO}_{2} \mathrm{eq}$ during 1993-2007, and 55\% of the total CF was due to nitrogen fertilizer use-induced emissions. Similarly, Xue et al. (2016) reported that fertilizer application contributed the most to the CF and NF of a double rice production system. In addition, a previous study showed that the production and application of nitrogen fertilizer contributed $74 \%$ of the total GHG emissions from oilseed production in Canada (Gan et al. 2012). Therefore, strategies and culture techniques that can decrease the amount of nitrogen fertilizer needed and simultaneously achieve a low CF and NF and a high level of cost effectiveness are worth exploring.
Cover crops are most often used as catch crops to amend bare land during fallow periods (Blanco-Canqui et al. 2015; Thorup-Kristensen et al. 2003). Previous studies have reported that the root system of cover crops absorbs residual nitrogen from the soil during the fallow period, and this nitrogen can be used by subsequent crops after the roots decompose (Fosu et al. 2003). Therefore, compared with fallow treatments, cover crops should further reduce the amount of applied nitrogen required for subsequent crops and increase the yield of subsequent crops (Gabriel and Quemada, 2011; Tonitto et al. 2006). The use of cover crops that reduce the need for nitrogen fertilization could be an effective strategy to maximize high yields and minimize the $\mathrm{CF}$ and NF, thus increasing the ecological and economic benefits (Blanco-Canqui et al. 2015; Cai et al. 2018).

The Yellow River basin, one of the three cotton-producing areas in China, encompassed 17,486.68 ha and accounted for $38.65 \%$ of the area sown with cotton in China from 2000 to 2017 (DRESSBS 2018). The amount of nitrogen applied for cotton cultivation in the Yellow River basin is generally $187.5-270 \mathrm{~kg} \mathrm{ha}^{-1}$, which is $2.08 \sim 3$ times higher than the recommended amount $\left(90 \mathrm{~kg} \mathrm{ha}^{-1}\right)$ in the cotton belt of the USA (Mao 2013). The excessive application of nitrogen fertilizer during cotton cultivation can lead to high GHG emissions and losses of reactive nitrogen species to the surrounding environment (Liu et al., 2013; Zhang et al. 2013). In addition, single cropping has been the major cotton cropping system in the Yellow River basin over the last decade, with cotton fields remaining fallow for 6 months, from the first frost to the following April, greatly wasting land and natural resources (Mao 2013). Therefore, planting February orchid instead of leaving the bare land fallow in a cotton cropping system (Fig. 1) may reduce the amount of nitrogen fertilizer needed and may increase cotton yields, thus increasing the
Fig. 1 Cotton field before February orchid turning over.

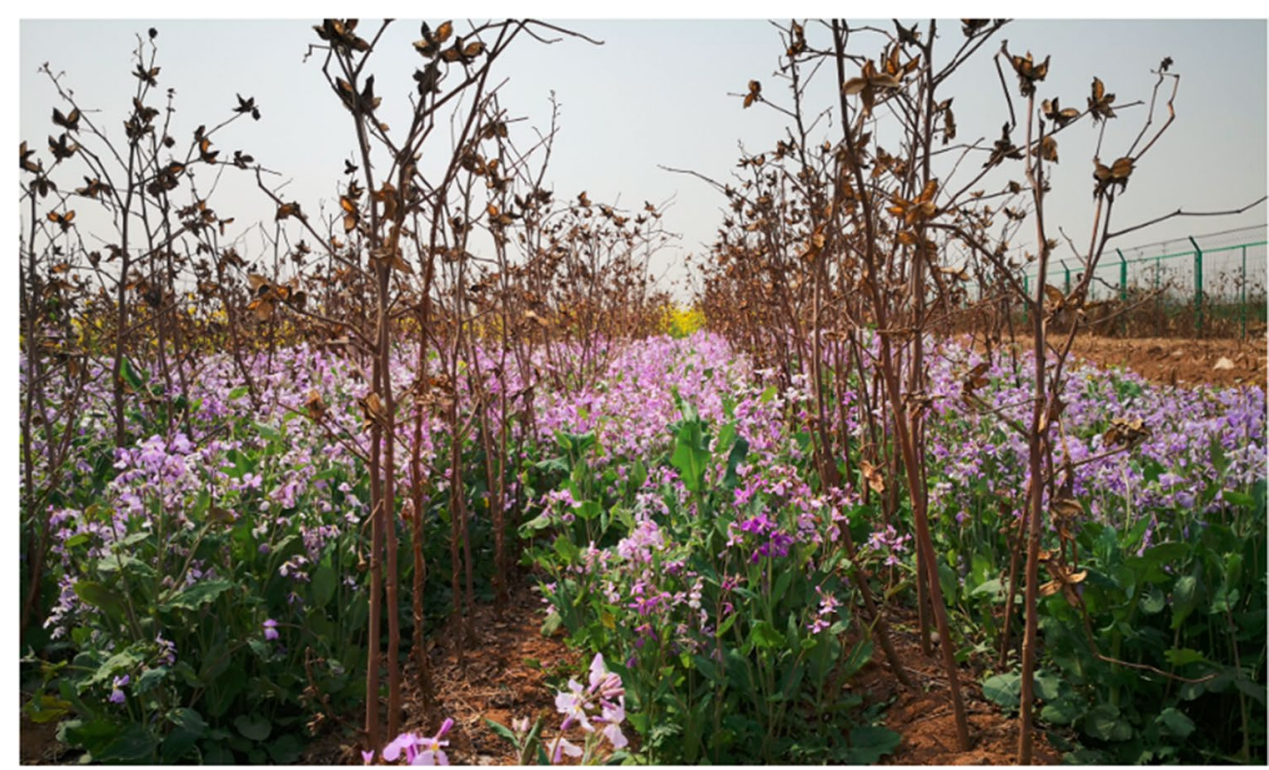


Fig. 2 Temporal distribution of cotton and cover crops in the two cropping systems. CWF cotton-winter fallow; CFO cotton-February orchid.

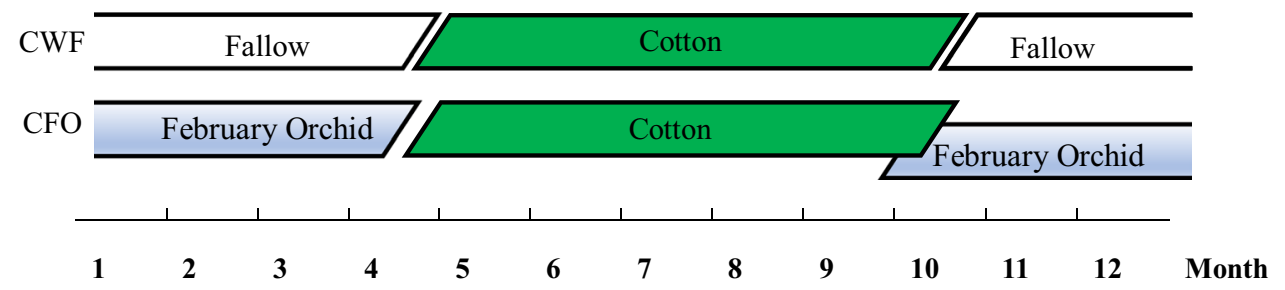

net ecosystem economic benefits (NEEB). Replacing winter bare fallow with cover crops in cotton production is a novel cropping system in China that may also be a low-carbon cropping system (Scavo et al. 2020). However, there are no studies that analyze the replacement of bare fallow land with February orchid as a cover crop to reduce nitrogen fertilization in cotton cropping systems by using the $\mathrm{CF}$ and NF methods, even though this information may provide insight into sustainable agricultural development.

Therefore, we evaluated two different cotton cropping systems (cotton-winter fallow and cotton/February orchid) with reduced nitrogen inputs in the Yellow River basin of China. The hypothesis of the present study is that the cotton/ February orchid system with reduced nitrogen input would increase ecological and economic benefits in the cotton production system. Specifically, the objectives of the study were (1) to compare the GHG emissions and CFs of the different systems, (2) to compare the reactive nitrogen emissions and NFs of the treatments, and (3) to evaluate the ecological and economic benefits of the two different cotton cropping systems (cotton-winter fallow and cotton/February orchid) with reduced nitrogen inputs in the Yellow River basin of China.

\section{Materials and methods}

\subsection{Climate and soil at the study site}

The experiment was conducted at the eastern experimental station of the Institute of Cotton Research of the Chinese Academy of Agricultural Sciences ( $36^{\circ} 06^{\prime} \mathrm{N}, 114^{\circ} 21^{\prime} \mathrm{E}$, with an elevation of $76 \mathrm{~m}$ ) (Fig. 2). The station is located in the Yellow River basin of China. The average annual temperature is $13.6{ }^{\circ} \mathrm{C}$, the annual precipitation is $650 \mathrm{~mm}$, and the frost-free period is 200 days. The average temperature and rainfall of the experimental station are at the average level of the Yellow River basin of China, which represents the climate of this region (Figs. S1 and S2). Cotton-winter fallow cropping is the main cropping system, which accounts for $70-80 \%$ of the cotton cropping system in the Yellow River basin of China after 2000 (Mao 2013). The experimental site has clay loam soil, which is the main soil type in this region (Mao 2013). The initial properties of the topsoil were as follows: $\mathrm{pH}$ of 8.1 , organic matter content of $16.27 \mathrm{~g} \mathrm{~kg}^{-1}$, total nitrogen content of $1.16 \mathrm{~g} \mathrm{~kg}^{-1}$, and available $\mathrm{P}$ and $\mathrm{K}$ contents of 12.27 and $162.00 \mathrm{mg} \mathrm{kg}^{-1}$, respectively.

\subsection{Experimental design for crop management}

Two different cotton cropping systems (a cotton-winter fallow cropping system (CWF) and a cotton/February orchid cropping system (CFO)) under four nitrogen application rates $\left(0 \mathrm{~kg} \mathrm{~N} \mathrm{ha}^{-1}\right.$ (N0), $112.5 \mathrm{~kg} \mathrm{~N} \mathrm{ha}^{-1}$ (N1), $168.75 \mathrm{~kg} \mathrm{~N} \mathrm{ha}^{-1}(\mathrm{~N} 2)$, and $225 \mathrm{~kg} \mathrm{~N} \mathrm{ha}^{-1}(\mathrm{~N} 3)$ ) were arranged in a randomized block design with three replicates. $\mathrm{N} 3$ is the conventional nitrogen fertilizer application rate in the study area, and N2 and N1 are the amounts of nitrogen applied by reducing nitrogen fertilizer by $1 / 4$ and $1 / 2$, respectively. N0 represents the treatment without nitrogen treatment. Plots were $10 \mathrm{~m} \times 6 \mathrm{~m}$ with three replicates, and the row spacing was $0.76 \mathrm{~m}$. The planting distribution of cotton and February orchid over 1 year in the two cropping systems is shown in Fig. 2: (1) the CWF was a monoculture cropping system with cotton and a winter fallow period, and (2) the CFO was an intercropping system consisting of February orchid intercropped with cotton during the later developmental stage of cotton, followed by crushing and pressing of February orchid to return it to the field before cotton was sown in the next year.

The cotton hybrid CRI 60, one of the most popular cotton hybrids in the Yellow River basin, was used in this study. The cotton was planted on 21 April 2017, 21 April 2018, and 24 April 2019. February orchid was sown by hand at the time of cotton harvesting, which was performed on 5 October 2017 and 10 October 2018. In the experiment, chemical phosphate and potassium fertilizers were applied at $102 \mathrm{~kg} \mathrm{ha}^{-1}$ each. Half of the nitrogen fertilizer was used as the basal fertilizer, and the other half was used as the top fertilizer during the flowering and boll setting periods. Phosphate and potassium fertilizers were applied once with basal fertilizer. All fertilizers were applied during the growing season of cotton, i.e., not during the growing season of February orchid. The nitrogen, phosphate, and potash fertilizers were in the form of urea $(46 \% \mathrm{~N})$, calcium superphosphate $\left(12 \% \mathrm{P}_{2} \mathrm{O}_{5}\right)$, and potassium sulfate $\left(52 \% \mathrm{~K}_{2} \mathrm{O}\right)$, respectively. The removal of weeds and insects and other management practices were conducted according to local agronomic practices. 


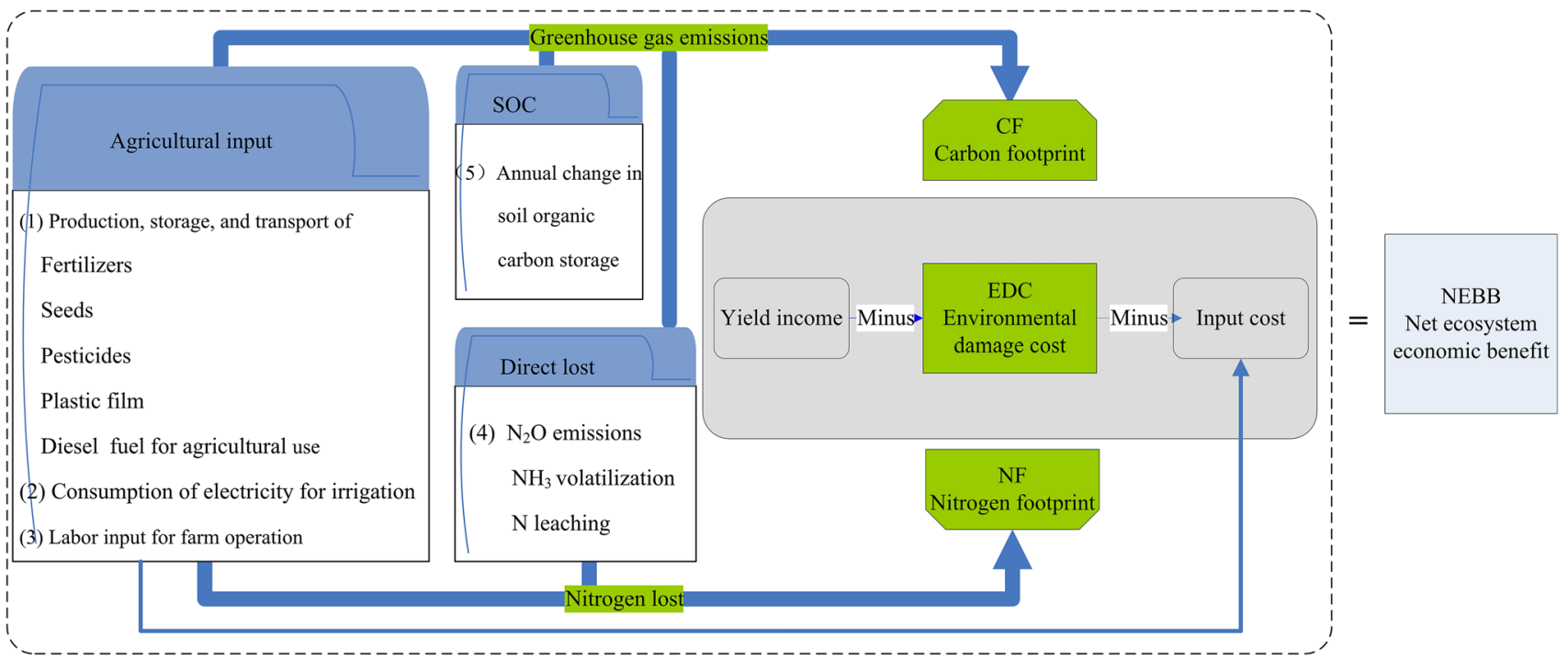

Fig. 3 System boundaries for the life cycle assessment of the carbon footprint, nitrogen footprint, and net ecosystem economic benefit in cotton production. SOC soil organic carbon.

\subsection{System boundary and functional units}

In this study, the system boundaries extended from the cradle to the farm gate based on the LCA method (Pandey and Agrawal 2014), which includes all GHG emissions and nitrogen losses during cotton production (Fig. 3). The GHG emissions and nitrogen emissions were generated by the following: (1) the production, storage, and transport of agricultural inputs (e.g., mulching film, pesticides, seeds, fertilizers, and diesel fuel for the agricultural machinery); (2) the consumption of electricity for irrigation; (3) the input of labor, which included artificial topping, artificial harvesting and the operation of machinery to seed, weed, and so on; (4) the direct GHG emissions and nitrogen losses from the cotton field (e.g., $\mathrm{N}_{2} \mathrm{O}$ emission, $\mathrm{NH}_{3}$ volatilization, and nitrogen leaching); and (5) the annual change in soil organic carbon (SOC) storage. In addition, most of the harvested seed cotton was sold as a commodity; thus, the equivalent sown area of cotton (ha), yield ( $\mathrm{kg}$ ), production value (CNY), and economic benefit $(\mathrm{CNY})$ were defined as the functional units of both the CF and NF. The production value is the total revenue from the harvested seed cotton, and the economic benefit is the net income generated by a cotton system.

\subsection{The CF calculation}

The CF values were estimated based on the LCA method, which involved the following equations (Gan., 2012; Wang et al. 2019; Yang et al. 2014):
$C F_{a}=\frac{\sum_{i}\left(A I_{i} \times E F_{i}+N_{2} O_{F I E L D}+\Delta C\right)}{\text { Sown area }}$

$C F_{y}=\frac{\sum_{i}\left(A I_{i} \times E F_{i}+N_{2} O_{F I E L D}+\Delta C\right)}{\text { Yield }}$

$C F_{v}=\frac{\sum_{i}\left(A I_{i} \times E F_{i}+N_{2} O_{\text {FIELD }}+\Delta C\right)}{\text { Production value }}$

$C F_{e}=\frac{\sum_{i}\left(A I_{i} \times E F_{i}+N_{2} O_{\text {FIELD }}+\Delta C\right)}{\text { Economic benefit }}$

where $\mathrm{CF}_{a}, \mathrm{CF}_{y}, \mathrm{CF}_{v}$, and $\mathrm{CF}_{e}$ represent the $\mathrm{CF}$ of cotton production per unit of sown area $\left(\mathrm{kg} \mathrm{CO}_{2} \mathrm{eq} \mathrm{ha}^{-1}\right)$, cotton yield $\left(\mathrm{kg} \mathrm{CO}_{2} \mathrm{eq} \mathrm{kg}^{-1}\right)$, production value $\left(\mathrm{kg} \mathrm{CO}_{2} \mathrm{eq} \mathrm{CNY}^{-1}\right)$, and economic benefit $\left(\mathrm{kg} \mathrm{CO}_{2}\right.$ eq $\left.\mathrm{CNY}^{-1}\right)$ per year, respectively; $\mathrm{AI}_{i}$ represents the agricultural inputs applied during cotton production, which are presented in Table 1; $\mathrm{EF}_{i}$ represents the GHG emission factor of each agricultural input, which are presented in Table 2; $\Delta C$ represents the GHG emissions from the change in SOC in the field soil; and yield, production value, and economic benefit are the respective seed cotton yield $\left(\mathrm{kg} \mathrm{ha}^{-1}\right)$, production value $\left(\mathrm{CNY} \mathrm{ha}{ }^{-1}\right)$, and economic benefit $\left(\mathrm{CNY} \mathrm{ha}{ }^{-1}\right)$ of cotton production each year. The values for the yield, production value, and economic benefit in this study are presented in Table S1.

$\mathrm{N}_{2} \mathrm{O}_{\text {FIELD }}$ represents the $\mathrm{N}_{2} \mathrm{O}$ emissions from a cotton field. $\mathrm{N}_{2} \mathrm{O}_{\text {FIELD }}$ was calculated using Eqs. (5) and (6): 


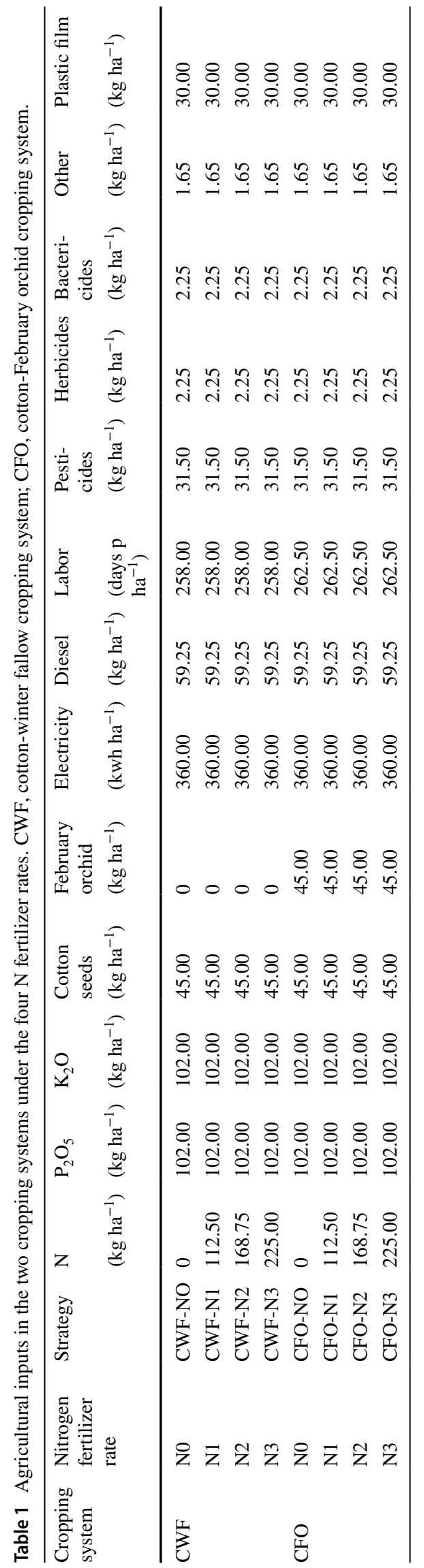

$\mathrm{N}_{2} \mathrm{O}_{\text {FIELD }}=\mathrm{N}_{2} \mathrm{O}_{\text {DIRECT }}+\mathrm{CO}_{2} e q_{G A S M}+\mathrm{CO}_{2} e q_{L E A C H}$

where $\mathrm{N}_{2} \mathrm{O}_{\text {FIELD }}$ represents the GHG emissions from the cotton field, $\mathrm{N}_{2} \mathrm{O}_{\text {DIRECT }}$ represents the direct $\mathrm{N}_{2} \mathrm{O}$ emissions from the cotton field $\left(\mathrm{kg} \mathrm{CO}_{2} \mathrm{eq} \mathrm{ha}^{-1}\right), \mathrm{CO}_{2} \mathrm{eq}_{\mathrm{GASM}}$ represents the indirect $\mathrm{N}_{2} \mathrm{O}$ emissions from the cotton field via ammonia volatilization, and $\mathrm{CO}_{2} \mathrm{eq}_{\mathrm{LEACH}}$ represents the indirect $\mathrm{N}_{2} \mathrm{O}$ emissions from the cotton field via nitrate leaching. The direct $\mathrm{N}_{2} \mathrm{O}$ emissions were determined by a static chamber method (Wang et al. 2016), and the $\mathrm{NH}_{3}$ volatilization from the cotton field was determined by a ventilation method (Jantalia et al. 2012). The static chamber method and ventilation method are described below (Sect. 2.7). The nitrate leached from a cotton field was calculated as follows (Gan et al. 2012):

$C \mathrm{O}_{2} e q_{L E A C H}=Q_{N F} \times P E R C_{L E A C H} \times E F_{L E A C H} \times \frac{44}{28} \times 298$

$\mathrm{CO}_{2} \mathrm{eq}_{\text {LEACH }}$ represents the indirect $\mathrm{N}_{2} \mathrm{O}$ emissions from a cotton field, which is the nitrate leached from the cotton field; $Q_{\mathrm{SNF}}$ represents the quantity of applied chemical nitrogen fertilizer $\left(\mathrm{kg} \mathrm{N} \mathrm{ha}^{-1}\right)$; PERC $_{\text {LEACH }}$ represents the percentage of nitrogen fertilizer that is lost due to nitrate leaching; $\mathrm{EF}_{\text {LEACH }}$ represents the $\mathrm{N}_{2} \mathrm{O}$ emissions due to nitrate leaching $\left(\mathrm{EF}_{\mathrm{LEACH}}\right.$ of cotton is $0.0075 \mathrm{~kg} \mathrm{~N} \mathrm{~kg}^{-1} \mathrm{~N}$ ); $44 / 28$ is the molecular weight coefficient for the conversion between $\mathrm{N}_{2} \mathrm{O}$ and $\mathrm{N}_{2}$; and 298 is the global warming potential $\left(\mathrm{CO}_{2} \mathrm{eq}\right)$ per unit of $\mathrm{N}_{2} \mathrm{O}$.

According to the publicly available specification 2050, the GHG emissions from crop production include GHG emissions from agricultural inputs and non- $\mathrm{CO}_{2}$ emissions from farmland, except for soil SOC changes (British Standards Institute 2011). However, an increasing number of experts have called for the inclusion of SOC changes in agricultural GHG emission assessments (Wang et al. 2021). Therefore, the estimated GHG emissions included SOC change in this study. The GHG emissions due to changes in SOC were calculated using Eq. (7) (Wang et al. 2021):

$\Delta \mathrm{C}=\frac{S O C_{2017}-S O C_{2019}}{2} \times \frac{44}{12}$

where $\Delta C$ is the average annual GHG emissions due to the change in SOC from 2017 to $2019\left(\mathrm{~kg} \mathrm{CO}_{2} \mathrm{eq} \mathrm{ha}^{-1} \mathrm{a}^{-1}\right)$; $\mathrm{SOC}_{2017}$ and $\mathrm{SOC}_{2019}$ are the reserves of SOC in the top layer of soil $(0-0.3 \mathrm{~m})$ in 2017 and 2019, respectively; 2 is the length of time that the trial was conducted; and 44/12 is the molecular weight coefficient for the conversion between $\mathrm{CO}_{2}$ and $\mathrm{C}$. 
Table 2 Agricultural inputs and their greenhouse gas (GHG) emission and reactive nitrogen emission coefficients considered during the estimation.

\begin{tabular}{llll}
\hline Input & $\begin{array}{l}\text { GHG } \\
\text { emission coefficient }\end{array}$ & $\begin{array}{l}\text { Reactive nitrogen } \\
\text { emission coefficient }\end{array}$ & Source \\
\hline Urea & $2.39 \mathrm{~kg} \mathrm{CO}_{2} \mathrm{eq} \mathrm{kg}^{-1}$ & $0.30 \mathrm{~g} \mathrm{Neq} \mathrm{kg}^{-1}$ & CLCD v0.7 \\
Calcium superphosphate & $0.30 \mathrm{~kg} \mathrm{CO}_{2} \mathrm{eq} \mathrm{kg}^{-1}$ & $0.60 \mathrm{~g} \mathrm{Neq} \mathrm{kg}^{-1}$ & CLCD v0.7 \\
Potassium sulfate & $0.25 \mathrm{~kg} \mathrm{CO}_{2} \mathrm{eq} \mathrm{kg}^{-1}$ & $0.02 \mathrm{~g} \mathrm{Neq} \mathrm{kg}^{-1}$ & CLCD v0.7 \\
Electricity for irrigation & $1.23 \mathrm{~kg} \mathrm{CO}_{2} \mathrm{eq} \mathrm{kwh}^{-1}$ & $0.11 \mathrm{~g} \mathrm{Neq} \mathrm{kg}^{-1}$ & CLCD v0.7 \\
Diesel & $0.89 \mathrm{~kg} \mathrm{CO}_{2} \mathrm{eq} \mathrm{kg}^{-1}$ & $0.06 \mathrm{~g} \mathrm{Neq} \mathrm{kg}^{-1}$ & CLCD v0.7 \\
Diesel combustion & $4.1 \mathrm{~kg} \mathrm{CO}_{2} \mathrm{eq} \mathrm{kg}^{-1}$ & $3.45 \mathrm{~g} \mathrm{Neq} \mathrm{kg}^{-1}$ & CLCD v0.7 \\
Labor & $0.86 \mathrm{~kg} \mathrm{CO}_{2} \mathrm{eq} \mathrm{days} \mathrm{p}^{-1}$ & - & Liu et al., 2013 \\
Plastic film & $22.72 \mathrm{~kg} \mathrm{CO}_{2} \mathrm{eq} \mathrm{kg}^{-1}$ & $12.02 \mathrm{~g} \mathrm{Neq} \mathrm{kg}^{-1}$ & Ecoinvent v2.2 \\
Seeds & $0.35 \mathrm{~kg} \mathrm{CO}_{2} \mathrm{eq} \mathrm{kg}^{-1}$ & $7.87 \mathrm{~g} \mathrm{Neq} \mathrm{kg}^{-1}$ & Ecoinvent v2.2 \\
Herbicides & $10.15 \mathrm{~kg} \mathrm{CO}_{2} \mathrm{eq} \mathrm{kg}^{-1}$ & $4.49 \mathrm{~g} \mathrm{Neq} \mathrm{kg}^{-1}$ & Ecoinvent v2.2 \\
Bactericides & $10.57 \mathrm{~kg} \mathrm{CO}_{2} \mathrm{eq} \mathrm{kg}^{-1}$ & $7.05 \mathrm{~g} \mathrm{Neq} \mathrm{kg}^{-1}$ & Ecoinvent v2.2 \\
Pesticides & $16.61 \mathrm{~kg} \mathrm{CO}_{2} \mathrm{eq} \mathrm{kg}^{-1}$ & $3.55 \mathrm{~g} \mathrm{Neq} \mathrm{kg}^{-1}$ & Ecoinvent v2.2 \\
Other agricultural chemicals & $12.44 \mathrm{~kg} \mathrm{CO}_{2} \mathrm{eq} \mathrm{kg}^{-1}$ & $11.50 \mathrm{~g} \mathrm{Neq} \mathrm{kg}^{-1}$ & Ecoinvent v2.2 \\
\hline
\end{tabular}

\subsection{The NF calculation}

The NF values were estimated based on the LCA method, which involved Eqs. (8)-(13) (Xue et al. 2016):

$$
\begin{aligned}
& N F_{a}=\frac{\sum_{i}\left(A I_{i} \times E F_{i}+N_{e q}{ }_{F I E L D}\right)}{\text { Sown area }} \\
& N F_{y}=\frac{\sum_{i}\left(A I_{i} \times E F_{i}+N_{e q F I E L D}\right)}{\text { Yield }} \\
& \left.N F_{v}=\frac{\sum_{i}\left(A I_{i} \times E F_{i}+N_{\text {eq }}\right. \text { FIELD }}{}\right) \\
& N F_{e}=\frac{\sum_{i}\left(A I_{i} \times E F_{i}+N_{e q F I E L D}\right)}{\text { Economic benefit }} \\
& N e q_{F I E L D}=N_{2} O_{D I R E C T}+N e q_{G A S M}+N e q_{L E A C H} \\
& N e q_{L E A C H}=Q_{S N F} \times P E R C_{L E A C H} \times E F_{L E A C H} \times \frac{44}{28} \times 1000
\end{aligned}
$$

where $\mathrm{NF}_{a}, \mathrm{NF}_{y}, \mathrm{NF}_{v}$, and $\mathrm{NF}_{e}$ represent $\mathrm{NF}$ of the cotton production per unit of sown area $\left(\mathrm{kg} \mathrm{Neq} \mathrm{ha}^{-1}\right)$, cotton yield $\left(\mathrm{kg} \mathrm{Neq} \mathrm{kg}^{-1}\right)$, production value $\left(\mathrm{kg} \mathrm{Neq} \mathrm{CNY}^{-1}\right)$, and economic benefit ( $\mathrm{kg} \mathrm{Neq} \mathrm{CNY}^{-1}$ ) per year, respectively; $\mathrm{EF}_{i}$ represents the specific nitrogen loss factors for each agricultural input, which are listed in Table 1; $\mathrm{N}_{2} \mathrm{O}_{\text {FIELD }}$ represents the $\mathrm{N}_{2} \mathrm{O}-\mathrm{N}$ emissions from farmland; $\mathrm{N}_{\text {eqFIELD }}$ represents the nitrogen lost from a cotton field; $\mathrm{N}_{2} \mathrm{O}_{\text {DIRECT }}$ represents the direct $\mathrm{N}_{2} \mathrm{O}-\mathrm{N}$ emissions from a cotton field $\left(\mathrm{kg} \mathrm{Neq} \mathrm{ha}^{-1}\right)$; $\mathrm{Neq}_{\mathrm{GASM}}$ represents ammonia volatilization from a cotton field; and $\mathrm{Neq}_{\mathrm{LEACH}}$ represents nitrate leaching from a cotton field. The direct $\mathrm{N}_{2} \mathrm{O}-\mathrm{N}$ emissions were determined by a static chamber method (Wang et al. 2016), the $\mathrm{NH}_{3}$ volatilization from a cotton field was determined by a ventilation method (Jantalia et al. 2012), and the nitrate leaching from a cotton field was calculated using Eq. (13).

\subsection{Environmental damage cost (EDC) and NEEB}

The EDC $\left(\mathrm{CNY} \mathrm{ha}{ }^{-1}\right)$ is the environmental cost of climate warming from $\mathrm{GHG}$ emissions and aquatic eutrophication from nitrogen loss from agricultural systems and was determined by Eq. (14) (Xia and Yan 2012):

$\mathrm{EDC}=C F_{a} \times P_{\mathrm{CO} 2}+N F_{a} \times P_{N}$

where $P_{\mathrm{CO} 2}\left(272.8 \mathrm{CNY} \mathrm{t}^{-1}\right)$ is the $\mathrm{EDC}$ (in terms of climate change) per unit of $\mathrm{CO}_{2}$ (Melaku Canu et al. 2015; Tol 2008) and $P_{\mathrm{N}}\left(4.26 \mathrm{CNY} \mathrm{kg} \mathrm{Neq}{ }^{-1}\right)$ is the EDC (in terms of human health and ecosystems) per unit of nitrogen lost (USDA, 2000; Xia and Yan 2012). The NEEB (CNY ha $\left.{ }^{-1}\right)$ of cotton production was assessed using Eq. (15) (Cai et al. 2018):

$N E E B=$ yield income - input cost $-E D C$

where yield income $\left(\mathrm{CNY} \mathrm{ha}^{-1}\right)$ is the output of the seed cotton yield and input cost $\left(\mathrm{CNY} \mathrm{ha}{ }^{-1}\right)$ is the total cost to purchase the agricultural inputs, which included agricultural capital investments (e.g., mulching film, pesticides, seeds, fertilizers, and diesel fuel for the agricultural machinery) and labor inputs (e.g., artificial topping, artificial harvesting and the operation of machinery for seeding and weeding).

\subsection{Data collection}

$\mathrm{N}_{2} \mathrm{O}$ emitted from the field was collected using a static chamber method (Wang et al. 2016). The static chamber 
was made of polyvinyl chloride, with a bottom area of $20 \mathrm{~cm} \times 20 \mathrm{~cm}$ and a height of $29.5 \mathrm{~cm}$. $\mathrm{N}_{2} \mathrm{O}$ was collected once per week throughout the entire study period and once every other day for 3 separate periods after fertilizer application and precipitation throughout the year. The $\mathrm{N}_{2} \mathrm{O}$ samples were collected mostly between 09:00 and 11:00 with 50-mL polypropylene syringes $0,10,20$, and $30 \mathrm{~min}$ after the chamber was closed; the $\mathrm{N}_{2} \mathrm{O}$ gas was collected into evacuated vials. At the beginning of the experiment, the chamber base was inserted to a depth of $5 \mathrm{~cm}$ in the soil at the center of each plot and left there until the test was completed to avoid disturbing the soil.

The $\mathrm{N}_{2} \mathrm{O}$ gas samples were analyzed by gas chromatography with electron capture detection (model $1876890 \mathrm{~N}$, Agilent Technologies, Santa Clara, CA, USA). The $\mathrm{N}_{2} \mathrm{O}$ flux was calculated using Eq. (16) (Robertson 1993):

$\mathrm{F}=\frac{44 \mathrm{HP}}{8.314 \times(273.2+T)} \times \frac{d c}{d t}$

where $F$ represents the $\mathrm{N}_{2} \mathrm{O}$ emission flux $\left(\mathrm{mg} \mathrm{m}^{-2} \mathrm{~min}^{-1}\right)$, 44 is the molecular weight of $\mathrm{N}_{2} \mathrm{O}\left(\mathrm{g} \mathrm{mol}^{-1}\right), H$ represents the height $(\mathrm{m})$ of the static chamber, $P$ represents the atmospheric pressure $(\mathrm{Pa}), 8.314$ is the ideal gas constant $\left(\mathrm{J} \mathrm{mol}^{-1} \mathrm{~K}^{-1}\right), T$ represents the average air temperature at the time of sampling $\left({ }^{\circ} \mathrm{C}\right)$, and $d c / d t$ represents the rate of change in the $\mathrm{N}_{2} \mathrm{O}$ gas concentration. The cumulative $\mathrm{N}_{2} \mathrm{O}$ emissions were calculated assuming the existence of linear changes in gas fluxes between two successive sampling dates.

Ammonia volatilized from the field was collected using a ventilation method (Jantalia et al. 2012). During the basal fertilizer application and top dressing period, one collection device for volatilized ammonia was inserted to a depth of $5 \mathrm{~cm}$ in the soil at the center of each plot on the day after fertilization, and then samples were taken on the 1st, 2nd, 3rd, 4th, 5th, 6th, 7th, 10th, 13th, 20th, 27th, and 34th days after fertilization. The sampling started at 16:00 each day. The collection device for volatilized ammonia consisted of a polyvinyl chloride (PVC) pipe with an inner diameter of $15 \mathrm{~cm}$ and a height of $10 \mathrm{~cm}$.

Ammonium nitrogen was determined by indophenol blue colorimetry. The ammonia volatilization flux was calculated using Eq. (17) (Robertson 1993):

$F a=0.5 \times \sum_{i}^{n}\left(\left(v_{i} \times v_{i-1}\right) \times\left(T_{i} \times T_{i-1}\right)\right)$

where $F a$ represents the cumulative loss due to ammonia volatilization $\left(\mathrm{kg} \mathrm{ha}^{-1}\right), n$ represents the total number of determinations after fertilization, $i$ is the ammonia volatilization rate at the $i$ th determination $\left(\mathrm{kg} \mathrm{ha}^{-1} \mathrm{day}^{-1}\right), T_{i}$ is the number of days after fertilization that the $i$ th determination occurred, and $T_{i-1}$ is the time interval between two adjacent determination dates (days).

\subsection{Statistical analysis}

Analysis of variance (ANOVA) with all data was performed in SPSS 11.0 (SPSS Inc., Chicago, IL) and EXCEL 2017. Means between treatments were compared with the least significant differences (LSD) method at the $P=0.05$ significance level.

\section{Results}

\subsection{Greenhouse gas emissions}

The cropping system and nitrogen application rate significantly impacted the total GHG emissions (Fig. 4; Table S2). Compared with the CWF system, the CFO system significantly increased the GHG emissions from agricultural inputs and the cotton field because the CFO system increased direct and indirect $\mathrm{N}_{2} \mathrm{O}$ emissions from the field by $7.5-38.7 \%$ and $0.2-5.8 \%$, respectively, in addition to increasing the labor input. The GHG emissions from agricultural inputs and cotton fields decreased with the decrease in the nitrogen application rate, largely due to the increasing GHG emissions from increasing nitrogen inputs (production, storage, and transport), direct $\mathrm{N}_{2} \mathrm{O}$ emissions from the field, and indirect $\mathrm{N}_{2} \mathrm{O}$ emissions from the field (ammonia volatilization and nitrate leaching). The direct and indirect $\mathrm{N}_{2} \mathrm{O}$ emissions from the field decreased by $16.3-61.9 \%$ and $22.9-95.0 \%$, respectively, as the nitrogen fertilization rate decreased $(P<0.05)$.

Under different cropping systems and nitrogen application rates, the change in SOC had a strong influence on the total GHG emissions (Fig. 3; Table S2). In this study, the GHG emissions from the change in SOC were negative, which indicated that the change in SOC served as a carbon sink, thus offsetting the total GHG emissions in this study. Compared to those in the CWF system, the GHG emissions from the SOC changes in the CFO system were significantly decreased, by $82.0 \%, 83.7 \%, 95.8 \%$, and $93.9 \%$ under the N0, N1, N2, and N3 application rates, respectively $(P<0.05)$. The SOC decreased with the decrease in the nitrogen application rate. Compared to that in the N3 treatment (the conventional nitrogen application rate), SOC decreased significantly, by $6.2 \%, 18.0 \%$, and $49.7 \%$, under $\mathrm{N} 2, \mathrm{~N} 1$, and $\mathrm{N} 0$ in the CWF cropping system and by $5.54 \%$, $22.16 \%$, and $50.92 \%$ under $\mathrm{N} 2, \mathrm{~N} 1$, and N0 in the CFO cropping system $(P<0.05)$.

The largest component of the total GHG emissions was nitrogen fertilizer, followed by $\mathrm{N}_{2} \mathrm{O}$ emissions, plastic film, pesticide, electricity for irrigation, indirect $\mathrm{N}_{2} \mathrm{O}$ emissions, phosphate fertilizer, diesel combustion, labor, diesel, potash fertilizer, seeds, bactericides, and other farm chemicals. Among the components of GHG emissions, nitrogen 
Fig. 4 Contributions of the different sources of greenhouse gas (GHG) emissions under the different cropping systems with four nitrogen application treatments. CWF, cotton-winter fallow cropping system; $\mathrm{CFO}$, cotton-February orchid cropping system. Others: GHG emissions from phosphate fertilizer, potash fertilizer, pesticides, plastic film, diesel fuel and electricity.

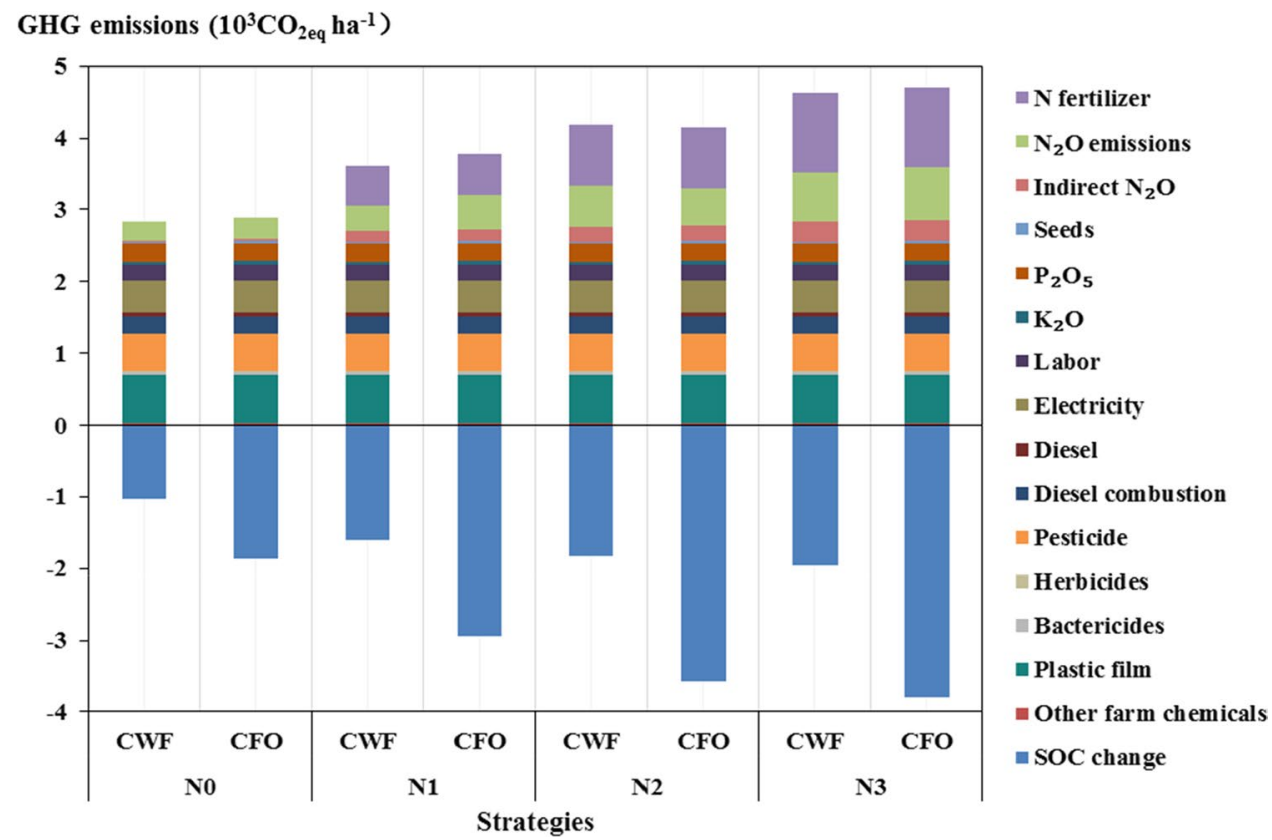

fertilizer, $\mathrm{N}_{2} \mathrm{O}$ emissions, plastic film, pesticides, and electricity for irrigation were the major sources of emissions, which accounted for $23.9 \%, 15.7 \%, 14.4 \%$, and $11.1 \%$, respectively, of the total emissions in the CWF-N3 treatment. Furthermore, the SOC changes were negative in this study, which offset $36.2-80.4 \%$ of the total GHG emissions.

\subsection{Carbon footprints}

The cropping system and nitrogen application rate significantly impacted the CFs (Fig. 5). Compared with the CWF system, the CFO system significantly decreased the $\mathrm{CF}_{a}$, $\mathrm{CF}_{y}, \mathrm{CF}_{v}$, and $\mathrm{CF}_{e}$ by 43.6-76.1\%, 49.1-79.0\%, 46.6-76.6\%, and 49.1-78.8\%, respectively $(P<0.05)$. The $\mathrm{CF}_{a}, \mathrm{CF}_{y}, \mathrm{CF}_{v}$, and $\mathrm{CF}_{e}$ only decreased under the CWF system but first decreased and then increased under the CFO system as the nitrogen fertilization rate decreased. Furthermore, the $\mathrm{CF}$ of the CFO-N2 strategy was the lowest CF of the entire study, and the $\mathrm{CF}_{a}, \mathrm{CF}_{y}, \mathrm{CF}_{v}$, and $\mathrm{CF}_{e}$ of the CFO-N2 strategy were significantly lower than those of the CWF-N3 strategy by $79.0 \%, 79.0 \%, 79.3 \%$, and $78.8 \%$, respectively.

\subsection{Nitrogen emissions}

Both the cropping system and nitrogen application rate significantly impacted the nitrogen emissions (Fig. 6). The nitrogen emissions in the CFO system were high because of $\mathrm{N}_{2} \mathrm{O}$ emissions from the field and from planted seeds. Compared with the CWF system, the CFO system significantly increased the $\mathrm{N}_{2} \mathrm{O}$ emissions from the field and from the planted seeds by $7.5-38.7 \%$ and $100 \%$, respectively $(P<0.05)$. The nitrogen emissions decreased with the decrease in the nitrogen application rate, largely because the reduction in the nitrogen fertilization rate decreased not only the nitrogen emissions from the nitrogen fertilization but also the $\mathrm{N}_{2} \mathrm{O}$ emissions and $\mathrm{NH}_{3}$ volatilization from the field by $16.3-61.9 \%$ and $10.5-65.5 \%$, respectively.

The components of total nitrogen emissions were volatilized $\mathrm{NH}_{3}$, followed by $\mathrm{N}_{2} \mathrm{O}$ emissions, seeds, phosphate fertilizer, nitrogen leaching and runoff, plastic film, diesel combustion, pesticides, nitrogen fertilizer, electricity for irrigation, other farm chemicals, bactericides, herbicides, potash fertilizer, and diesel. The main components of the nitrogen emissions were volatilized $\mathrm{NH}_{3}$ and $\mathrm{N}_{2} \mathrm{O}$, which together accounted for $64.5-78.9 \%$ of the total nitrogen emissions. The largest source of GHG emissions was $\mathrm{NH}_{3}$ volatilization, which accounted for $56.1-76.2 \%$ of the total nitrogen emissions.

\subsection{Nitrogen footprints}

Both the cropping system and nitrogen application rate impacted the NFs (Fig. 7). Compared with the CWF system, the CFO system significantly increased the $\mathrm{NF}_{a}$ by $11.5 \%, 6.7 \%, 10.0 \%$, and $6.7 \%$ under the N0, N1, N2, and N3 application rates, respectively $(P<0.05)$. The CFO system significantly increased the $\mathrm{NF}_{y}$ and $\mathrm{NF}_{v}$ under the four nitrogen application rates except in the $\mathrm{N} 2$ treatments. The $\mathrm{CFO}$ system decreased the $\mathrm{NF}_{e}$ under the four nitrogen application rates except in the $\mathrm{N} 3$ treatments. Furthermore, $\mathrm{NF}_{a}$, $\mathrm{NF}_{y}$, and $\mathrm{NF}_{v}$ decreased with decreasing nitrogen application rate. Overall, the CWF-N0 strategy had the lowest NF in the entire study, with $\mathrm{NFs}, \mathrm{NF}_{y}, \mathrm{NF}_{v}$, and $\mathrm{NF}_{e}$ values that 
Fig. $5 \mathrm{CF}_{a}, \mathrm{CF}_{y}, \mathrm{CF}_{v}$, and $\mathrm{CF}_{e}$ of the two cropping systems with four nitrogen application rates. CWF: cotton-winter fallow cropping system; CFO: cotton-February orchid cropping system; $\mathrm{CF}_{a}, \mathrm{CF}_{y}, \mathrm{CF}_{v}$, and $\mathrm{CF}_{e}$ represent the carbon footprint of cotton production per unit of sown area, cotton yield, production value and economic benefit per year, respectively.

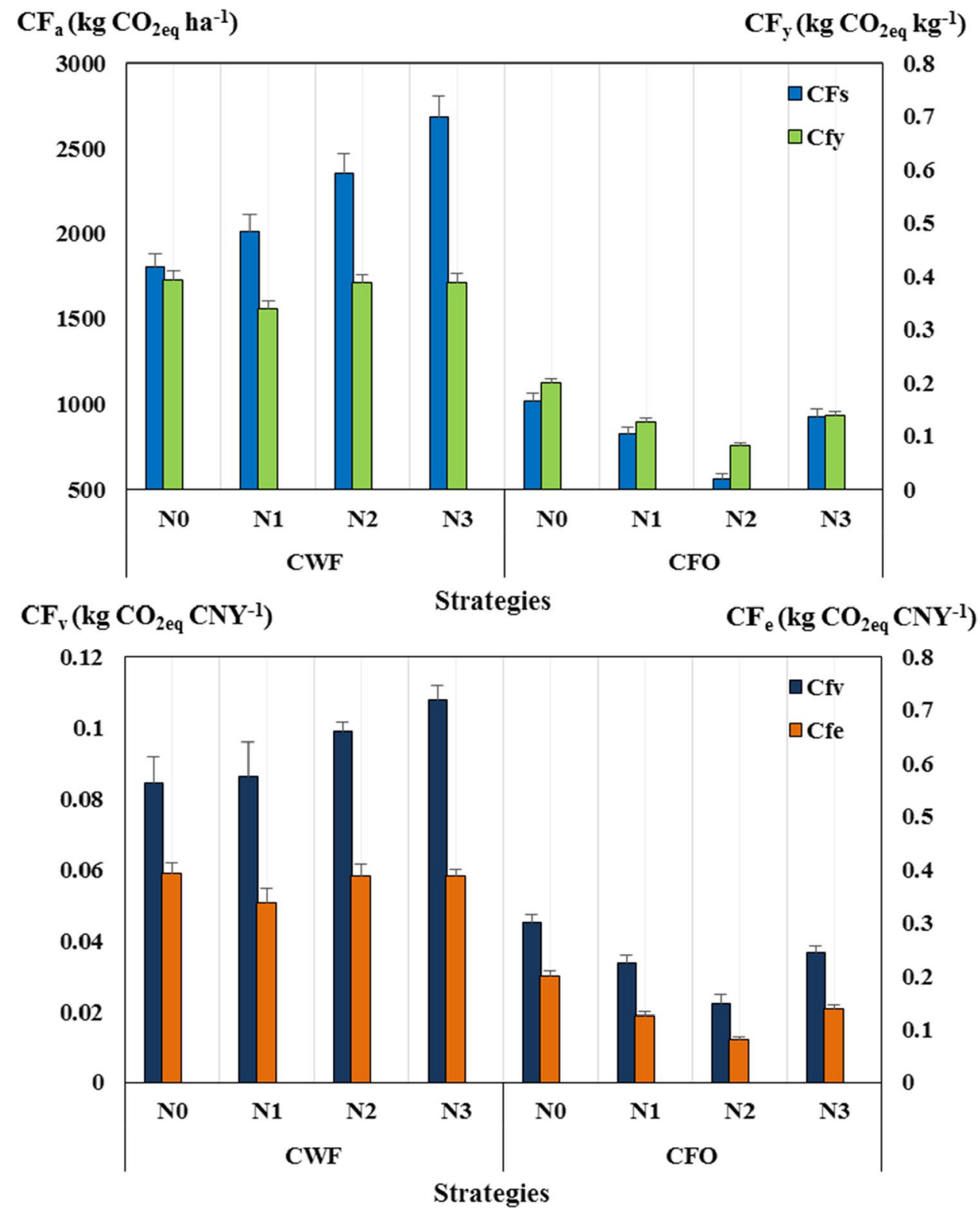

were $59.2 \%, 52.4 \%, 52.4 \%$, and $38.4 \%$ lower, respectively $(P<0.05)$, than those for the CWF-N3 strategy.

\subsection{The NEEB and economic benefits}

The effects of the cropping systems on the NEEB and economic benefits are consistent with the other results discussed above (Fig. 8). Compared with the CWF system, the CFO system increased the NEEB by $3.2 \%, 24.7 \%, 16.8 \%$, and $17.3 \%$ and increased the economic benefits by $-4.0 \%$, $13.9 \%, 9.8 \%$, and $10.7 \%$ under the N0, N1, N2, and N3 application rates, respectively. In addition, the NEEB and economic benefits decreased in the CWF system with the reduction in the nitrogen application rate; however, in the CFO system, the NEEB and economic benefits first increased and then decreased. The CFO-N2 strategy had the highest NEEB and economic benefits in the entire study (Fig. 9); compared with the CWF-N3 strategy, the CFO-N2 strategy increased the NEEB by $9.5 \%$ and resulted in roughly the same level of economic benefits.

\section{Discussion}

\subsection{The effect of the cropping system and nitrogen application rate on GHG emissions and the CF}

The results showed that the direct and indirect $\mathrm{N}_{2} \mathrm{O}$ emissions from the CFO field were higher than those from the CWF field, which indicated that the planting and turnover 
Fig. 6 Contributions of the different sources of nitrogen emissions under the different cropping systems with four nitrogen application rates. CWF, cotton-winter fallow cropping system; CFO, cotton-February orchid cropping system.

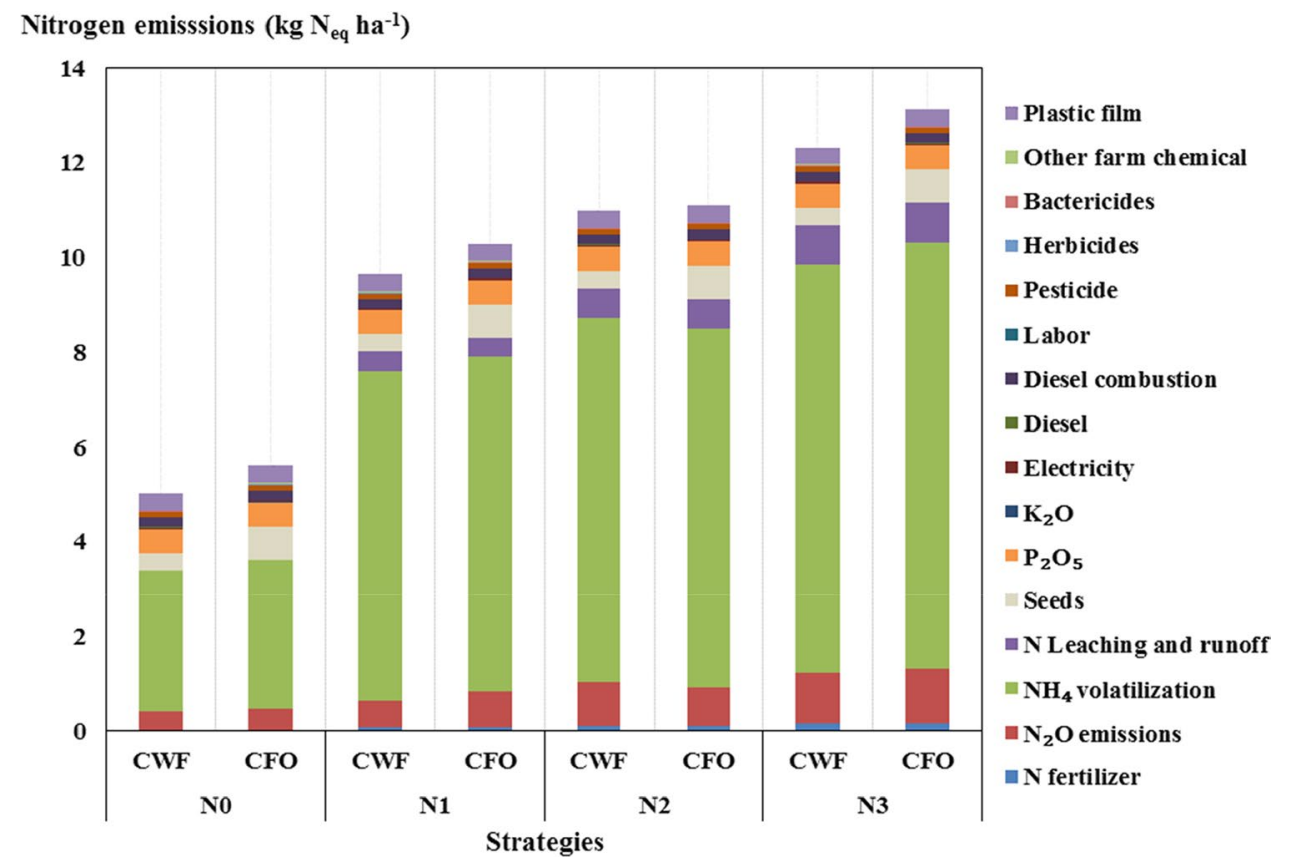

of February orchid in winter fallow cotton fields increased the direct and indirect $\mathrm{N}_{2} \mathrm{O}$ emissions; the above results are different from those in a previous study (Sanz-Cobena et al. 2014). Muhammada et al. (2019) explored the effect of cover crops on $\mathrm{N}_{2} \mathrm{O}$ emissions through a meta-analysis and found that $\mathrm{N}_{2} \mathrm{O}$ emissions were lower with cover crops than without cover crops. The reason for the differences in these results might be due to differences in the biomass yields, residual carbon/nitrogen ratios of the crops and metabolic activities of the soil rhizosphere (Basche et al. 2014; SanzCobena et al. 2014). Furthermore, the results of the present work showed that GHG emissions increased due to the increased emissions from planted seeds and labor activities associated with the CFO system. Therefore, the CFO system not only increased GHG emissions due to agricultural inputs but also increased $\mathrm{N}_{2} \mathrm{O}$ emissions from the field. However, GHG emissions caused by changes in SOC were negative because SOC changes in the CFO system increased the absolute value of GHG emissions; thus, an increase in soil carbon reserves would offset some of the GHG emissions. Therefore, the planting and turnover effect of February orchid in a winter fallow cotton field decreased GHG emissions mainly because of the increase in SOC.

As expected, decreases in direct and indirect $\mathrm{N}_{2} \mathrm{O}$ emissions were observed with the reduction in the nitrogen fertilization rate, and this finding is consistent with the results of previous studies (Maharjan et al. 2014; Marie et al. 2019). Numerous studies have shown that $\mathrm{N}_{2} \mathrm{O}$ emissions from field soils are directly related to the application rate of chemical nitrogen fertilizer (Hoben et al. 2011; Sapkota et al. 2020). Therefore, a reduction in fertilizer use is one of the main strategies for reducing $\mathrm{N}_{2} \mathrm{O}$ emissions from farmland (Wang et al. 2016). However, the SOC increased with increasing nitrogen application, which offset or even exceeded the GHG emissions caused by the nitrogen application; this might have been due to the increase in the SOC, which was caused by the increase in crop biomass and straw turnover when nitrogen fertilizer was applied (Dong et al. 2012). Therefore, when reducing the amount of fertilizer in the future, the effect of straw turnover on the increase in SOC should be considered.

Under the same nitrogen application rate, $\mathrm{CF}_{a}, \mathrm{CF}_{y}, \mathrm{CF}_{v}$, and $\mathrm{CF}_{e}$ in the $\mathrm{CFO}$ system were lower than those in the CWF system. Furthermore, the CF decreased in the CWF system; however, in the CFO system, the CF first decreased and then increased with the reduction in the application of chemical nitrogen fertilizer. Both of these results indicated that the planting and turnover of February orchid in a winter fallow cotton field could reduce the total GHG emissions while increasing the production value and economic benefits, especially with a low rate of nitrogen fertilizer application. In addition, the CFO-N2 strategy had the lowest CF of the entire study. Therefore, the CFO cropping system with the $\mathrm{N} 2$ application rate was the most sustainable strategy among the eight tested strategies when considering only GHG emissions, which was considered the environmental cost in this study.

\subsection{The effect of the cropping system and nitrogen application rate on nitrogen emissions and NF}

The CFO system increased the nitrogen emissions from planted seeds, $\mathrm{NH}_{3}$ volatilization, and $\mathrm{N}_{2} \mathrm{O}$ emissions. These 
Fig. $7 \mathrm{NF}_{a}, \mathrm{NF}_{y}, \mathrm{NF}_{v}$, and $\mathrm{NF}_{e}$ of the two cropping systems with four nitrogen application rates. $\mathrm{NF}_{a}, \mathrm{NF}_{y}, \mathrm{NF}_{v}$, and $\mathrm{NF}_{e}$ represent the nitrogen footprint of cotton production per unit of sown area, cotton yield, production value, and economic benefit per year, respectively; CWF, cotton-winter fallow cropping system; CFO, cotton-February orchid cropping system.
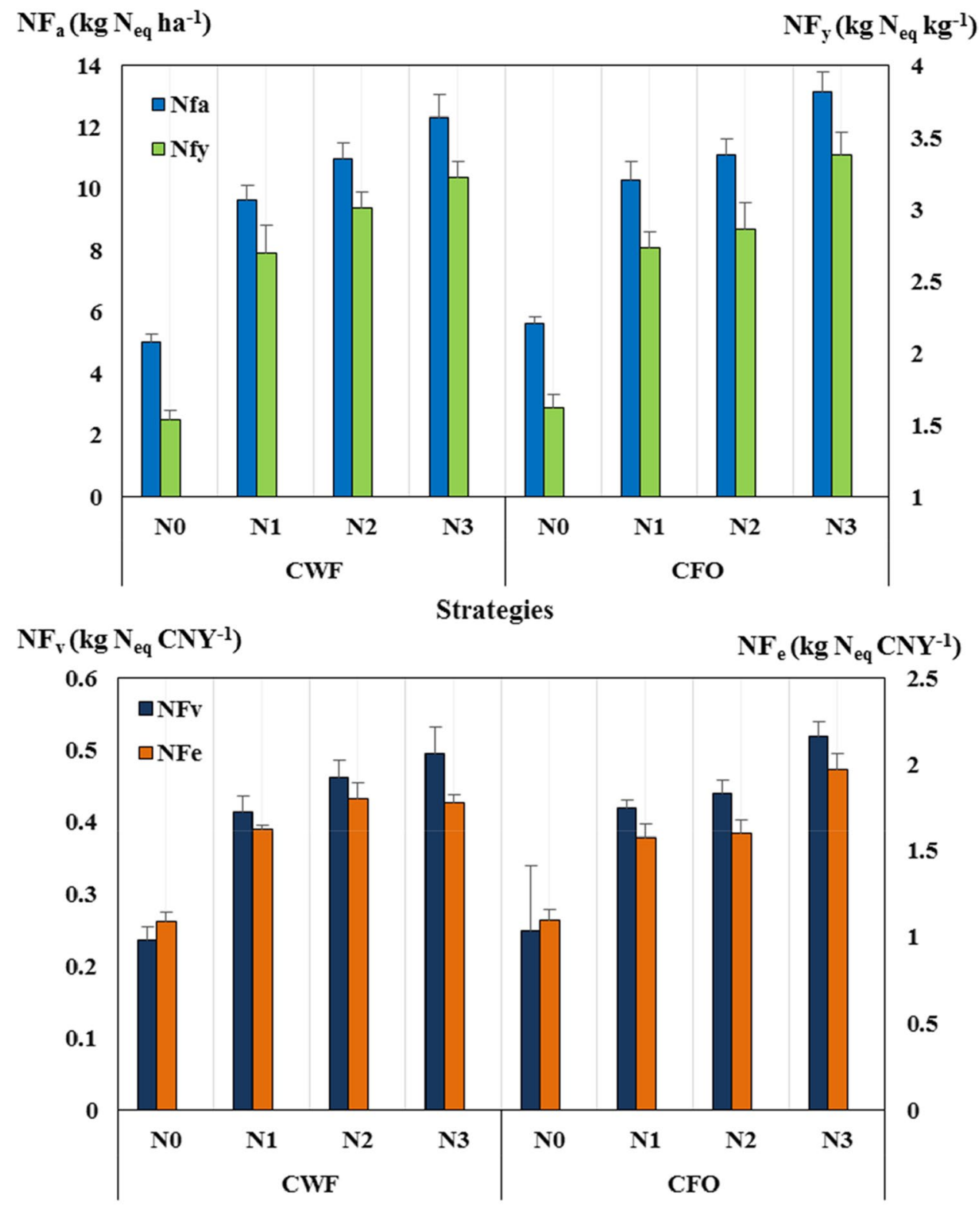

Strategies results are inconsistent with those of previous studies showing that the use of cover crops decreased $\mathrm{N}_{2} \mathrm{O}$ emissions but did not affect $\mathrm{NH}_{3}$ volatilization (Mitchell et al. 2013; Sanz-Cobena et al. 2014). This difference might be due to differences in the residual carbon/nitrogen ratio, lignin content, metabolic activity, and respiration in the soil rhizosphere resulting from differences in the cover crop species (Muhammada et al. 2019). Thus, the adoption of a strategy that uses cover crops to reduce nitrogen emissions must consider the type of cover crop (Basche et al. 2014). In addition, the nitrogen emissions caused by $\mathrm{NH}_{3}$ volatilization and the $\mathrm{N}_{2} \mathrm{O}$ emissions decreased with the reduction in the nitrogen fertilization rate, which is consistent with previous research results (Misselbrook et al. 2004; Ramanantenasoa et al. 2019). Thus, a reduction in nitrogen fertilizer use from farmland remains one of the main strategies to reduce nitrogen emissions (Wang et al. 2016).

$\mathrm{NF}$ is an important indicator for quantifying and assessing the magnitude of nitrogen loss from agroecosystems to mitigate environmental degradation (Xue et al. 2016). Reducing NF by optimizing farming practices is also an important measure for sustainable crop production (Xue et al. 2016). The $\mathrm{NF}_{a}$ of the $\mathrm{CFO}$ system was higher than that of the CWF system, which might have been due to the increase in agricultural input and the $\mathrm{NH}_{3}$ and $\mathrm{N}_{2} \mathrm{O}$ emissions from the field (Fig. 4). Furthermore, $\mathrm{NF}_{y}, \mathrm{NF}_{v}$, and $\mathrm{NF}_{e}$ were higher with the CFO system than in the CWF system, except under the $\mathrm{N} 2$ and $\mathrm{N} 3$ application rates. This indicated that optimizing 
Fig. 8 Net ecosystem economic benefit (NEEB) and economic benefits of the two cropping systems with four nitrogen application rates. CWF, cottonwinter fallow cropping system; CFO, cotton-February orchid cropping system.
Fig. 9 Net ecosystem economic benefit (NEEB) and economic benefit of the different strategies. CWF, cotton-winter fallow cropping system; CFO, cottonFebruary orchid cropping system.

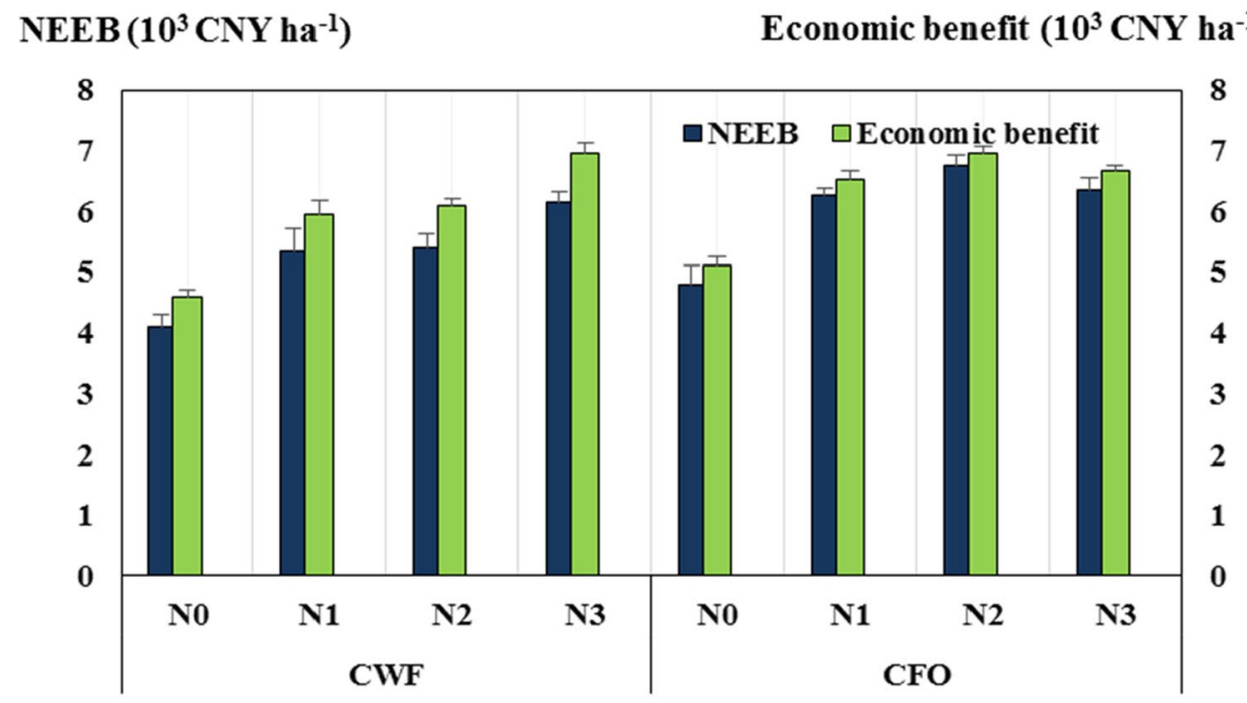

Strategies

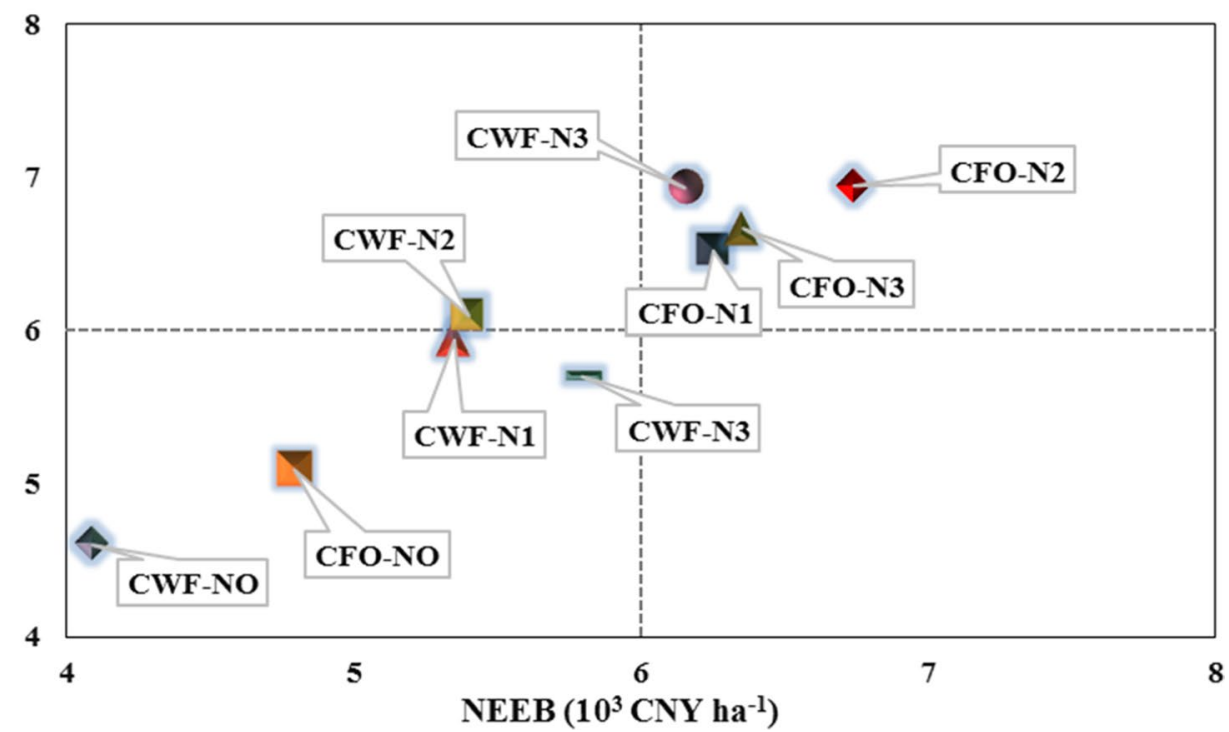

the ratio of fertilizer and organic fertilizer could reduce NF (Guardia et al. 2019).

In this study, the NFs decreased with the reduction in the nitrogen fertilization rate, which might have been due to the decrease in nitrogen fertilizer applied and the $\mathrm{NH}_{3}$ and $\mathrm{N}_{2} \mathrm{O}$ emissions from the field. This result is consistent with that of a previous study in which yield-scaled nitrous oxide emissions were obtained at the lowest nitrogen application rates in a winter wheat-summer maize double-cropping system (Qin et al. 2012). Within the scope of this study, the increase in nitrogen fertilizer also increased $\mathrm{NF}_{y}, \mathrm{NF}_{v}$, and $\mathrm{NF}_{e}$, which indicated that increases in the yield, output value, and economic benefits could not compensate for the increase in nitrogen emissions. The CWF-N0 strategy, which was a cropping system with a single crop of cotton that was not fertilized, had the lowest NF in this study but also the lowest economic and ecological benefits, which is consistent with previous research results (Zhou et al. 2019).

\subsection{The effects of the cropping system and nitrogen application rate on the ecological and economic benefits}

An increased economic benefit is generally the primary factor that motivates farmers to improve farming practices (Zhou et al. 2019). However, for governments, improvements to farming practices offer not only economic benefits but also ecological benefits (Wang et al. 2017). Thus, if 
farming practices can improve economic and environmental benefits at the same time, they are sustainable and well implemented.

When changes in GHG emissions were calculated to assess the ecological benefits, $\mathrm{CF}_{a}, \mathrm{CF}_{y}, \mathrm{CF} v$, and $\mathrm{CF}_{e}$ in the CFO system were lower than those in the CWF system because the CFO system greatly increased the SOC, despite the $\mathrm{CFO}$ system increasing the input emissions and the direct and indirect $\mathrm{N}_{2} \mathrm{O}$ emissions from the field. However, when changes in nitrogen emissions were calculated to assess the ecological benefits, $\mathrm{NF}_{a}, \mathrm{NF}_{y}, \mathrm{NF}_{v}$, and $\mathrm{NF}_{e}$ in the CFO system were higher than those in the CWF system, while $\mathrm{NF}$ decreased with reduced nitrogen fertilizer application rates. These results indicated that the ecological benefits of the different farming measures might vary under different ecological objectives (Wang et al. 2019).

When changes in both nitrogen loss and GHG emissions were calculated to assess the ecological benefits, both the NEEB and economic benefits in the CWF system decreased with reduced nitrogen fertilizer application. However, in the CFO system, the NEEB and economic benefits first increased and then decreased. The above result indicated that the amount of nitrogen fertilizer could be reduced to obtain economic and ecological benefits in the CFO system but not in the CWF system. Furthermore, the CFO-N2 strategy had the highest economic and ecological benefits between the two cropping systems under the four nitrogen fertilization rates. Therefore, the use of February orchid as a cover crop in cotton production would be a sustainable strategy that reduces the use of nitrogen fertilizer by $25 \%$ while ensuring economic and ecological benefits. Bai et al. (2015) found that integrated application of February orchid as a cover crop with a $30 \%$ reduction in nitrogen fertilizer increased maize grain yield while decreasing apparent nitrogen loss. Zhang et al. (2021) found that cotton/Orychophragmus violaceus increased the soil organic matter, total nitrogen, and available nitrogen compared to cotton-fallow at a $0-100-\mathrm{cm}$ soil depth. As shown in Table 1, the CFO system increased the labor time by $1.74 \%$ (4.5 days $\mathrm{p} \mathrm{ha}^{-1}$ ), compared with the CWF system. Therefore, there are differences in labor time between cropping systems, but the differences were very small. Furthermore, the differences in labor time were mainly due to the CFO system having the labor of artificial sowing of February orchid. As this study is a plot experiment, mechanical sowing was not possible. In terms of large-scale production in large fields, if mechanical sowing is used, the labor gap between the two cropping systems will be smaller. Therefore, these differences could not constitute obstacles to the adoption of more virtuous cropping systems. Thus, farmers should be motivated to use February orchid as a cover crop, and governments could introduce policies to encourage farmers to adopt this sustainable farming practice through publicity, promotion, and small subsidies from the financial sector in the Yellow River basin of China. The results could also be used as guidance and reference for cotton production under the same ecological conditions in other regions of the world.

\subsection{Limitations of this study}

In the calculation of the GHG and nitrogen emissions, the emissions from the field mainly included emitted $\mathrm{N}_{2} \mathrm{O}$, volatilized $\mathrm{NH}_{3}$, and leached nitrogen. The emissions from nitrogen leaching were estimated by an IPCC method (IPCC 2014), which might have influenced the absolute values of the CF, NF, and NEEB but had little effect on the results of this study because the extent of nitrogen leaching in the region was small. Furthermore, there is large uncertainty associated with the EDC per unit of $\mathrm{CO}_{2}$ in terms of climate change $\left(P_{\mathrm{CO} 2}\right)$ because of the different degrees of climate change and modeling of the $P_{\mathrm{CO} 2}$. The $P_{\mathrm{CO} 2}$ estimates from the voluntary agreements vary over a wide magnitude range from 2 to $101 € \mathrm{tCO}_{2} \mathrm{eq}^{-1}$ in different organizations and reports (Melaku Canu et al. 2015). Tol (2008) found a mean estimate of $272.8 \mathrm{CNY} \mathrm{tCO}_{2} \mathrm{eq}^{-1}$ for a fitted distribution with a $1 \%$ increase over time. Therefore, $272.8 \mathrm{CNY}$ $\mathrm{tCO}_{2} \mathrm{eq}^{-1}$ was used as the $P_{\mathrm{CO} 2}$ value in this study, even though this value has associated uncertainty.

In addition, although the site selected in this study is a representative site in the cotton region with the typical climate and soil characteristics of the Yellow River basin of China, there are limits. Addressing these challenges requires many additional field experimental sites in the future.

\section{Conclusions}

Our study showed that the CFO system decreased the CF mainly because of the increase in the SOC but increased the NF mainly because of the increase in $\mathrm{N}_{2} \mathrm{O}$ emissions and $\mathrm{NH}_{3}$ volatilization. Furthermore, the NEEB and economic benefits of the CFO system first increased and then decreased, but those of the CWF system decreased as the nitrogen fertilizer application rate decreased, which indicated that the CFO system could replace chemical nitrogen fertilizer in sustainable agricultural systems. In general, compared with conventional cropping systems and nitrogen fertilizer applications, the CFO-N2 strategy increased the NEEB by $9.5 \%$ in terms of economic benefits. Therefore, the replacement of winter bare fallow with a cover crop of February orchid in a cotton field along with a $25 \%$ reduction in the applied chemical nitrogen fertilizer is an appropriate alternative fertilization strategy that should be widely adopted by stakeholders to achieve sustainable cotton development in the Yellow River basin of China and other regions with similar ecological conditions. 
Supplementary Information The online version contains supplementary material available at https://doi.org/10.1007/s13593-021-00720-0.

Authors' contributions Zhanbiao Wang: conceptualization, formal analysis, investigation, writing - original draft, supervision, project administration, funding acquisition. Lichao Zhai: Writing - review and editing. Shiwu Xiong: investigation, data curation. Xiaofei Li: writing-review and editing. Yingchun Han: project administration. Guoping Wang: project administration. Lu Feng: formal analysis. Zhengyi Fan: investigation. Yaping Lei: formal analysis. Beifang Yang: investigation. Fangfang Xing: investigation. Minghua Xin: investigation. Wenli Du: investigation. Yabing Li: supervision, project administration, funding acquisition.

Funding This work was partly financed by the National Natural Science Foundation of China (31701389) and the Central Public-Interest Scientific Institution Basal Research Fund (1610162021037).

Data availability The datasets generated during and/or analyzed during the current study are available from the corresponding author on reasonable request.

Code availability Not applicable.

\section{Declarations}

Ethics approval Not applicable.

Consent to participate Not applicable.

Consent for publication All the authors whose names appeared on the submission approved the version to be published and agreed to be accountable for all aspects of the work in ensuring that the questions related to the accuracy of integrity of any part of the work were appropriately investigated and resolved.

Conflict of interest The authors declare no competing interests.

Open Access This article is licensed under a Creative Commons Attribution 4.0 International License, which permits use, sharing, adaptation, distribution and reproduction in any medium or format, as long as you give appropriate credit to the original author(s) and the source, provide a link to the Creative Commons licence, and indicate if changes were made. The images or other third party material in this article are included in the article's Creative Commons licence, unless indicated otherwise in a credit line to the material. If material is not included in the article's Creative Commons licence and your intended use is not permitted by statutory regulation or exceeds the permitted use, you will need to obtain permission directly from the copyright holder. To view a copy of this licence, visit http://creativecommons.org/licenses/by/4.0/.

\section{References}

Bai JS, Cao WD, Xiong J, Zeng NH, Gao SJ, Shimizu K (2015) Integrated application of February orchid (Orychophragmus violaceus) as green manure with chemical fertilizer for improving grain yield and reducing nitrogen losses in spring maize system in northern China. J Integr Agr 14(12):2490-2499. https://doi.org/ $10.1016 /$ S2095-3119(15)61212-6
Basche AD, Miguez FE, Kaspar TC, Castellano MJ (2014) Do cover crops increase or decrease nitrous oxide emissions? A Meta-Analysis J Soil Water Conserv 69:471-482. https://doi.org/10.2489/ jswc.69.6.471

Blanco-Canqui H, Shaver TM, Lindquist JL, Shapiro CA, Elmore RW, Francis CA, Hergert GW (2015) Cover crops and ecosystem services: insights from studies in temperate soils. Agron. J. 117:2449-2474. https://doi.org/10.2134/agronj15.0086

British Standards Institute (2011) Specification for the assessment of the life cycle greenhouse gas emissions of goods and services. Publicly available specification-PAS 2050: 2011. British Standards Institute, London

Cai SY, Pittelkow CM, Zha X, Wang SQ (2018) Winter legume-rice rotations can reduce nitrogen pollution and carbon footprint while maintaining net ecosystem economic benefits. J Clean Prod 195:289-300. https://doi.org/10.1016/j.jclepro.2018.05. 115

Cheng K, Pan GX, Smith P, Luo T, Li LQ, Zhang JW, Zhang XH, Han XJ, Yan M (2011) Carbon footprint of China's crop production-an estimation using agro statistics data over 1993-2007. Agr Ecosyst Environ 142:231-237. https://doi.org/10.1016/j.agee.2011.05.012

Department of Rural Social Economical Survey, State Bureau of Statistics (2018) China rural statistical yearbook (ed. Zhang, W. M.) Ch. 3, 37. China Statistics Press, Beijing

Dong HZ, Li WJ, Christensen BT, Eneji AE, Zhang DM (2012) Nitrogen rate and plant density effects on yield and late-season leaf senescence of cotton raised on a saline field. Field Crop Res 126:137-144. https://doi.org/10.1016/j.fcr.2011.10.00

Fosu M, Kühne RF, Vlek PG (2003) Recovery of cover-crop-N in the soil-plant system in the Guinea savannah zone of Ghana. Biolo Fert of Soils 39(2):117-122. https://doi.org/10.1007/ s00374-003-0677-3

Gabriel JL, Quemada M (2011) Replacing bare fallow with cover crops in a maize cropping system: yield, $\mathrm{N}$ uptake and fertiliser fate. Europ J Agronomy 34:133-143. https://doi.org/10.1016/j.eja. 2010.11.006

Galloway JN, Townsend AR, Erisman JW, Bekunda M, Cai Z, Freney JR, Mar-tinelli LA, Seitzinger SP, Sutton MA (2008) Transformation of the nitrogen cycle: recent trends, questions, and potential solutions. Science 320(5878):889-892. https://doi.org/10.1126/ science. 1136674

Gan YT, Liang C, Huang GB, Malhi SS, Brandt SA, KatepaMupondwa F (2012) Carbon footprint of canola and mustard is a function of the rate of $\mathrm{N}$ fertilizer. Int $\mathrm{J}$ Life Cycle Assess 17:58-68. https://doi.org/10.1007/s11367-011-0337-z

Guardia G, Aguilera E, Vallejo A, Sanz-Cobena A, Alonso-Ayuso M, Quemada M (2019) Effective climate change mitigation through cover cropping and integrated fertilization: a global warming potential assessment from a 10-year field experiment. J Clean Prod 2019(241):118307. https://doi.org/10.1016/j.jclepro.2019. 118307

Hoben JP, Gehl RJ, Millar N, Grace PR, Robertson GP (2011) Nonlinear nitrous oxide $\left(\mathrm{N}_{2} \mathrm{O}\right)$ response to nitrogen fertilizer in on-farm corn crops of the US Midwest. Glob Chang Biol 17:1140-1152. https://doi.org/10.1111/j.1365-2486.2010.02349.x

IPCC (2014) Climate change 2014: mitigation of climate change. In: von Stechow C, Zwickel T, Minx JC (eds) Edenhofer O, PichsMadruga R, Sokona Y, Farahani E, Kadner S, Seyboth K, Adler A, Baum I, Brunner S, Eickemeier P, Kriemann B, Savolainen J, Scho"mer S. Contribution of Working Group III to the Fifth Assessment Report of the Intergovernmental Panel on Climate Change. Cambridge University Press, Cambridge and New York

ISO 14067 (2013) Greenhouse gases - carbon footprint of products - requirements and guidelines for quantification and communication. Switzerland, Geneva 
Jantalia CP, Halvorson AD, Follett RF, Alves BJR, Polidoro JC, Urquiaga $S$ (2012) Nitrogen source effects on ammonia volatilization as measured with semi-static chambers. Agron J 104:1595-1603. https://doi.org/10.2134/agronj2012.0210

Ju XT, Xing GX, Chen XP, Zhang SL, Zhang LJ, Liu XJ, Cui ZL, Yin B, Christie P, Zhu ZL, Zhang FS (2009) Reducing environmental risk by improving $\mathrm{N}$ management in intensive Chinese agricultural systems. Proc Natl Acad Sci u s Am 106(9):3041-3046. https:// doi.org/10.1073/pnas.0813417106

Leach AM, Galloway JN, Bleeker A, Erisman JW, Kohn R, Kitzes J (2012) A nitrogen footprint model to help consumers understand their role in nitrogen losses to the environment. Environ Dev 1(1):40-66. https://doi.org/10.1016/j.envdev.2011.12.005

Liu XJ, Zhang Y, Han WX, Tang A, Shen JL, Cui ZL, Vitousek P, Erisman JW, Goulding K, Christie P, Fangmeier A, Zhang FS (2014) Enhanced nitrogen deposition over China. Nature 494(7438):459462. https://doi.org/10.1038/nature11917

Maharjan B, Venterea RT, Rosen C (2014) Fertilizer and irrigation management effects on nitrous oxide emissions and nitrate leaching. Agron J 106:703-714. https://doi.org/10.2134/agronj2013. 0179

Mao SC (2013) Cultivation of cotton in China. Science and Technology Press, Shanghai

Marie M, Ramanantenasoa J, Génermont S, Gilliot JC, Bedos C, Makowski D (2019) Meta-modeling methods for estimating ammonia volatilization from nitrogen fertilizer and manure applications. J Environ Manage 236:195-205. https://doi.org/10.1016/j. jenvman.2019.01.066

Melaku Canu D, Ghermandi A, Nunes P, Lazzari P, Cossarini G, Solidoro C (2015) Estimating the value of carbon sequestration ecosystem services in the Mediterranean Sea: an ecological economics approach. Global Environ Change 32:87-95. https://doi. org/10.1016/j.gloenvcha.2015.02.008

Misselbrook TH, Sutton MA, Scholefield D (2004) A simple processbased model for estimating ammonia emissions from agricultural land after fertilizer applications. Soil Use Manag 20:365-372. https://doi.org/10.1111/j.1475-2743.2004.tb00385.x

Mitchell DC, Castellano MJ, Sawyer JE, Pantoja J (2013) Cover crop effects on nitrous oxide emissions: role of mineralizable carbon. Soil Sci Soc Am J 77:1765-1773. https://doi.org/10.2136/sssaj 2013.02.0074

Muhammada I, Sainjub UM, Zhao FZ, Khanc A, Ghimired R, Fu X, Wang J (2019) Regulation of soil $\mathrm{CO}_{2}$ and $\mathrm{N}_{2} \mathrm{O}$ emissions by cover crops: a meta-analysis. Soil Til Res 192:103-112. https:// doi.org/10.1016/j.still.2019.04.020

Pandey D, Agrawal M (2014) Carbon footprint estimation in the agriculture sector. In: Muthu SS (ed) Assessment of carbon footprint in different industrial sectors, vol 1. Springer, Singapore

Qin SP, Wang YY, Hu CS, Oenema O, Li XX, Zhang YM, Dong WX (2012) Yield-scaled $\mathrm{N}_{2} \mathrm{O}$ emissions in a winter wheat-summer corn double-cropping system. Atmos Environ 5:240-244. https:// doi.org/10.1016/j.atmosenv.2012.02.077

Ramanantenasoa MMJ, Génermon S, Gilliot JM, Bedos C, Makowski D (2019) Meta-modeling methods for estimating ammonia volatilization from nitrogen fertilizer and manure applications. J Environ Manage 236:195-205. https://doi.org/10.1016/j.jenvm an.2019.01.066

Robertson, G.P., 1993. Fluxes of nitrous oxide and other nitrogen trace gases from intensively managed landscapes: a global perspective. In: Harpwr L.A., Mosier A.R., Duxbury J.M., Rolston D.E., (eds) Agricultural ecosystem effects on trace gases and global climate change. ASA Special Publication No. 55. ASA, CSSA, SSSA, Madison, wi 95-108.

Sanz-Cobena A, García-Marco S, Quemada M, Gabriel J, Almendros $\mathrm{P}$, Vallejo A (2014) Do cover crops enhance $\mathrm{N}_{2} \mathrm{O}, \mathrm{CO}_{2}$ or $\mathrm{CH}_{4}$ emissions from soil in Mediterranean arable systems? Sci Total
Environ 466:164-174. https://doi.org/10.1016/j.scitotenv.2013. 07.023

Sapkota T.B, Singh, LK, Yadav AK, Khatri-Chhetri A, Jat HS, Sharma PC, Jat ML, Stirling CM 2020 Identifying optimum rates of fertilizer nitrogen application to maximize economic return and minimize nitrous oxide emission from rice-wheat systems in the Indo-Gangetic Plains of India. Arch. Agron. Soil Sci. https://doi. org/10.1080/03650340.2019.1708332

Scavo A, Restuccia A, Lombardo S, Fontanazza S, Abbate C, Pandino G, Anastasi U, Onofri A, Mauromicale G (2020) Improving soil health, weed management and nitrogen dynamics by Trifolium subterraneum cover cropping. Agron. Sustain. Dev. 40(3):18-18. https://doi.org/10.1007/s13593-020-00621-8

Thorup-Kristensen K, Magid J, Jensen LS (2003) Catch crops and green manures as biological tools in nitrogen management in temperate zones. Adv Agron 79:227-227. https://doi.org/10.1016/ S0065-2113(02)79005-6

Tol RSJ (2008) The social cost of carbon: trends, outliers and catastrophes. economics: the open-access. Open-Assess E-J 2:2008-2025. https://doi.org/10.5018/economics-ejournal.ja.2008-25

Tonitto C, David MB, Drinkwater LE (2006) Replacing bare fallows with cover crops in fertilizer-intensive cropping Systems: a meta-analysis of crop yield and $\mathrm{N}$ dynamics. Agr Ecosyst Enviro 112(1):58-72. https://doi.org/10.1016/j.agee.2005.07.003

U.S. Department of Agriculture (USDA), 2000. Water quality impacts of agriculture. Washington, DC

Wang ZB, Zhang HL, Lu XH, Wang M, Chu QQ, Wen XY, Chen F (2016) Lowering carbon footprint of winter wheat by improving management practices in North China Plain. J Clean Prod 112:149-157. https://doi.org/10.1016/j.jclepro.2015.06.084

Wang ZB, Chen J, Mao SC, Han YC, Chen F, Zhang LF, Li YB, Li CD (2017) Comparison of greenhouse gas emissions of chemical fertilizer types in China's crop production. J Clean Prod 141:12671274. https://doi.org/10.1016/j.jclepro.2016.09.120

Wang ZB, Wang GP, Han YC, Feng L, Fan ZY, Lei YP, Yang BF, Li XF, Xiong SW, Xing FF, Xin MH, Du WL, Li CD, Li YB (2021) Improving cropping systems reduces the carbon footprints of wheat-cotton production under different soil fertility levels. Arch Argon Soil Sci 67:2, 218-233. https://doi.org/10.1080/03650340. 2020.1720912

Wang ZB, Zhang JZ, Zhang LF (2019) Reducing the carbon footprint per unit of economic benefit is a new method to accomplish lowcarbon agriculture. A case study: adjustment of the planting structure in Zhangbei County. China J Sci Food Agric 99:4889-4897. https://doi.org/10.1002/jsfa.9714

Warner K, Hamza M, Oliver-Smith A, Renaud F, Julca A (2010) Climate change, environmental degradation and migration. Nat Hazards 55(3):689-715. https://doi.org/10.1007/s11069-009-9419-7

West JR, Ruark MD, Shelley KB (2020) Sustainable intensification of corn silage cropping systems with winter rye. Agron Sustain Dev 40:11. https://doi.org/10.1007/s13593-020-00615-6

Xia YQ, Yan XY (2012) Ecologically optimal nitrogen application rates for rice cropping in the Taihu Lake Region of China. Sustain Sci 7(1):33-44. https://doi.org/10.1007/s11625-011-0144-2

Xue JF, Pu C, Liu SL, Zhao X, Zhang R, Chen F, Xiao XP, Zhang HL (2016) Carbon and nitrogen footprint of double rice production in Southern China. Ecol Indic 64:249-257. https://doi.org/10.1016/j. ecolind.2016.01.001

Yang XL, Sui P, Zhang M, Chen YQ, Gao WS (2014) Reducing agricultural carbon footprint through diversified crop rotation systems in the North China Plain. J Clean Prod 76:131-139. https://doi. org/10.1016/j.jclepro.2014.03.063

Zhang FS, Chen XP, Vitousek P (2013) Chinese agriculture: an experiment for the world. Nature 497(7447):33-35. https://doi.org/10. $1038 / 497033 a$ 
Zhang, Z.G., Li, X.F., Xiong, S.W., An, J., Han, Y.C., Wang, G.P., Feng, L., Lei, Y.P., Yang, B.F., Xing, F.F., Xin, M.H., Du, W.L. Wang, Z.B., Li, Y.B., 2021. Orychophragmus violaceus as a winter cover crop is more conducive to agricultural sustainability than Vicia villosa in cotton-fallow systems. Arch. Agron. Soil Sci. https://doi.org/10.1080/03650340.2021.1905800

Zhou J, Li B, Xia LL, Fan CH, Xiong ZQ (2019) Organic-substitute strategies reduced carbon and reactive nitrogen footprints and gained net ecosystem economic benefit for intensive vegetable productin. J Clean Prod 225:984-994. https://doi.org/10.1016/j. jclepro.2019.03.191

Publisher's note Springer Nature remains neutral with regard to jurisdictional claims in published maps and institutional affiliations. 